\title{
Russia's Eurasian past, present and future: rival international societies and Moscow's place in the post-cold war world
}

\section{Zachary Paikin, Kaneshko Sangar \& Camille-Renaud Merlen}

To cite this article: Zachary Paikin, Kaneshko Sangar \& Camille-Renaud Merlen (2018): Russia's Eurasian past, present and future: rival international societies and Moscow's place in the post-cold war world, European Politics and Society

To link to this article: https://doi.org/10.1080/23745118.2018.1545186

曲 Published online: 15 Nov 2018.

Submit your article to this journal $\widetilde{ }$

View Crossmark data $₫$ 


\title{
Russia's Eurasian past, present and future: rival international societies and Moscow's place in the post-cold war world
}

\author{
Zachary Paikin ${ }^{a}$, Kaneshko Sangar ${ }^{b}$ and Camille-Renaud Merlen (D) ${ }^{a, c}$ \\ ${ }^{a}$ Global Europe Centre, School of Politics and International Relations, University of Kent, Canterbury, UK; \\ ${ }^{\mathrm{b}}$ School of Slavonic and East European Studies, University College London, London, UK; ' ${ }^{\mathrm{S}}$ Chool of Politics and \\ International Relations, University of Kent, Canterbury, UK
}

\begin{abstract}
The failure of post-Soviet Russia to integrate into the West became evident with the 2014 Ukraine crisis, leading Moscow to accelerate its declared "pivot to the East". However, the increased dependence on China carries its own risks, such as the danger of becoming Beijing's junior partner. For an erstwhile superpower that continues to declare and prize its autonomy in international affairs, this is a particularly unappealing prospect. Thus, it remains to be seen whether a genuinely balanced partnership can exist between both countries. This article uses insights from Adam Watson's pendulum theory to explore Russia's post-2014 Eurasian predicament. We argue that the rapid rightward swing of the pendulum in the Euro-Atlantic order following the end of the Cold War has proven indigestible for Moscow. The article then moves to discuss the Sino-Russian relationship in the context of the emerging Eurasian space. It concludes that the growing disillusionment of Russian leaders with the West since the 2000s, along with the normative convergence between Moscow and Beijing, has led to a closer partnership between the two. Yet the partnership is also riddled with a number of insecurities on Moscow's side that could undermine the long-term prospects for cooperation between Russia and China.
\end{abstract}

\section{KEYWORDS}

Russia; China; Eurasia; world order; English school

\section{Introduction}

Following its annexation of Crimea in 2014, Russia began to accelerate its declared "pivot to the East". After nearly a quarter-century of failed attempts to produce a stable relationship with the United States and the European Union, this was the clearest signal yet that Russia would not - at least for the foreseeable future - become a part of the West. Trenin claims that the onset of the Ukraine crisis "essentially took Russia out of the post-Cold War international system" (Trenin, 2018b, pp. 20-2), which in turn raises questions about the future shape of world order.

Up until 2014, Russia had been caught between two primary - and arguably contradictory - goals. On the one hand, it wished to develop good relations with the West. On the other, it sought to retain its links with post-Soviet states and, where these had been 
disrupted by the dissolution of the Soviet Union, restore them (Kotkin, 2016). In the wake of the Ukraine crisis, however, Russia's pivot away from the West was not embodied exclusively in a desire to pursue deeper integration in the post-Soviet space. Rather, a new idea was put forward - that of "Greater Eurasia" (Karaganov, 2016). The notion of integrating the Eurasian supercontinent from Murmansk to Mumbai and from Minsk to Shanghai rather than the earlier "Lisbon to Vladivostok" formulation - places Russia in a resolutely and evolving Eurasian environment, although this "Greater Eurasia" project is said to remain open to EU participation in the future. China, too, has proposed its own vision for pan-regional integration in Eurasia - the Belt and Road Initiative (BRI) - and it remains an open question as to whether Moscow and Beijing's respective conceptions of Eurasian order can be reconciled, even though both sides have pledged to coordinate the BRI with the development of the Russian-led Eurasian Economic Union (EEU) (Sangar, 2017).

In this context, refusing to accept a role as Washington's junior partner could simply force Moscow into becoming Beijing's junior partner instead. This would be true under multiple scenarios: Friendly relations between the United States and China could definitively and unambiguously turn Russia into a second-tier power, but open conflict between Washington and Beijing could force Moscow to pick sides and thus relegate it to junior-partner status (Kaczmarski, 2015). Thus, Russia faces the difficult task of balancing between these two major power poles and finding a way to help build a "regional architecture to constrain the China-US rivalry" if it wishes to continue to be a major power in its own right (Kaczmarski, 2015). It is not difficult to see why this is important - both politically and psychologically - for a country that a mere three decades ago enjoyed the status of global superpower.

Moscow's supposed wariness of junior-partner status can likely, at least in part, be attributed to the circumstances surrounding its engrained material and psychological dependence upon the West in general and Europe more specifically. Viacheslav Morozov has characterized Russia as a "subaltern empire", the product of a modern history that has generated Russia's "simultaneous belonging to and exclusion from Europe" (2015, p. 41). These two Russian characteristics - both subaltern vis-à-vis Europe and yet a European empire at the same time - have resulted in an ambiguous identity. As Morozov puts it, "Russia has successfully colonized itself on behalf of Europe but has been unable to assimilate" $(2015$, p. 11). This difficulty, already present in Russian discourse for much of modern history, has been exacerbated by the circumstances surrounding the end of the Cold War, during which the West's goal was "Russia's adaptation to the stringencies of an existing order, not the creation of an expanded community", thus further entrenching Russia's subaltern position (Sakwa, 2017, p. 18). This impasse ultimately resulted in the onset of the 2014 Ukraine crisis and the beginning of Russia's proclaimed attempts to give birth to a Eurasian order.

This article seeks to explain why Russia-West ties deteriorated over the opening quarter-century of the post-Cold War era, as well as why Sino-Russian relations have remained on largely solid footing throughout this period in spite of Russia's relative decline and China's rise. It begins by using insights from English School theory, specifically the concepts of international society and Adam Watson's pendulum, to help understand Russia's post-2014 predicament in the broader Eurasian space. It then explores the conundrum Moscow has found itself in since 1991 in attempting to craft a durable and reliable model for its relations with the West and with Eurasia. From there it moves to discuss the 
evolving Sino-Russian relationship and its main challenges, before looking at the potential for more substantive normative agreement between the two countries.

\section{Competing international societies}

Perhaps the most developed concept put forward by the English School of international relations is the notion of "international society". Unlike international systems, which are usually rooted in a more Hobbesian or Machiavellian logic, international societies rely at least to a degree - on a common identity or set of norms that "define the boundaries of a social system", thus conditioning states' behaviour and laying the ground rules for what constitutes legitimate action (Buzan, 2014, pp. 12-13). English School theorists have indicated that the barrier for transition from international system to international society is in fact quite low. Martin Wight noted that a system of states - in which actors are strategically conscious of one another - usually does not come into being without at least a degree of cultural unity among its members (1977, p. 33). Moreover, Adam Watson, who conceived of international systems as pendula oscillating periodically between lesser and greater degrees of centralization, contended that all groupings of states that are more centralized or integrated than "absolute anarchy" - that is, featuring only "limited degrees of involvement between neighbours" - can be thought of as international societies, which "always originate within the matrix of a dominant culture" (although this notion has been challenged in recent scholarship; see, e.g. Dunne \& Reus-Smit, 2017) and where states are limited by impersonal pressures, rules and hegemonial authority (Watson, 1997, pp. 118-119).

We will return to why Watson's pendulum model is well suited to shed light on postCold War Russian foreign policy below, but for now let us explain how it functions in greater detail. The pendulum model outlines the degree of material and normative influence held by the leading state in any international society. The further to the right the pendulum swings, the greater degree of centralization. Multiple independencies (a completely decentralized society) at the leftmost extreme is followed to the right by hegemony, when a state becomes powerful enough to determine the foreign policy orientations of other states, then dominion, where the hegemon is able to influence the domestic affairs of these states, and then empire, when the borders dividing international centre and periphery begin to become blurred (Watson, 1997, pp. 118120). The reason the pendulum metaphor is employed, albeit imperfectly, is that a swing in one direction will, over time, ultimately give way to a swing in the opposite direction. Counterbalancing coalitions that seek to diffuse hegemony will emerge to oppose any state that threatens to become too powerful or influential. To quote Watson (1992, pp. 131-132), "the most stable point along the curve is not some invariable formula, but is the point of optimum mix of legitimacy and advantage, modified by the pull on our pendulum away from the extremes". Put differently, there must be both an agreed-upon legitimacy (rooted in both coercion and consent) that serves the interests of actors in the society, as well as a managed rapidity of the pendulum's movement in either direction. For instance, Napoleon's conquests represented a swing of the pendulum rightward toward centralization that was too rapid to be stable, resulting in a diffused hegemony agreed at Vienna being born in the wake of his defeat (Watson, 1992, p. 233). 
When it comes to Russia's position in the broader Eurasian supercontinent, then, the question is not whether the country is a part of an international society, but rather how normatively thin or thick that society is. Although today's global international society may be normatively thin, it is institutionally quite thick, and there exist global commitments on issues ranging from development to climate change. There is an additional consideration: As the world retreats from the unipolar moment of the 1990s, some scholars have contended that what lies ahead is not a new world order per se but rather several variably overlapping international orders, in addition to the (potentially evolving) global system we have today (see, e.g. Flockhart, 2016). What must be considered, therefore, is not the international society to which Russia belongs, but rather which international societies.

For the purposes of this paper, we can identify two such societies, which we call the Sino-Eurasian order and the Euro-Atlantic order. The idea of Europe has for centuries been the main "Other" against which the idea and identity of Russia has been defined (Neumann, 1995, p. 1), either by emulation or rejection of it or a combination of both (Morozov, 2015, p. 41), Moscow's interaction with international society has been strongly contingent upon the state of its relationship with Western states - the power base, as it were, of today's international order (Cox, 2013, p. 115). Indeed, particularly in the postCold War period, Russia's foreign policy behaviour has frequently been shaped in response to Western actions, ${ }^{1}$ in keeping with the notion of Russia's subaltern status, as mentioned above. The Euro-Atlantic order denoted here is a social one: It concerns Russia's relationship with Western states and is distinct from Euro-Atlantic political and security institutions such as the EU and NATO.

The Sino-Eurasian order, for its part, is distinct from the concept of "Greater Eurasia", which has the potential to include the European Union over the long term. Rather, it is rooted in the Sino-Russian relationship situated within the locus of an increasingly conscious Eurasian society. Importantly, it includes an understanding that Moscow's ties with other Asian polities - including Japan, South Korea and India - on high-level and first-order issues are strongly influenced by Russia's aims and concerns (1) vis-à-vis China, particularly to diversify its diplomatic and investment partnerships in Asia and to entrench multilateral mechanisms that secure its treatment as an equal, and (2) vis-à-vis the West, to balance against supposed Western excesses through bilateral diplomatic relationships or through institutions such as the BRICS. This is to say that, in effect, Russia's primary international orientation is determined by the state of its ties with both the West and China, with its other diplomatic relationships playing a largely peripheral if not epiphenomenal role.

An additional clarification is required, involving the precise meaning of the term order when referring to the two orders to which Russia belongs. Unlike Hedley Bull's characterization from The Anarchical Society that reduces international order to the forms of behaviour that maintain an international society, we use the definition from The Globalization of International Society that allows for a much closer relationship between order and society. As Dunne and Reus-Smit (2017, pp. 31, 33) put it:

A breakdown of international order is not merely a failure to realize the primary goals of the society of states; it is a failure of the rules and institutions that constitute that society. (...) 
[R]ather than seeing declining sociability as a marker of systemic politics, we see conflict and contestation as integral to any international social order.

This meshes quite well with Watson's pendulum model, which makes room for the existence of contestation and understands that a rapid swing can represent a fundamental threat to any sort of normative agreement within international society. The stability (or lack thereof) in the Sino-Russian and Euro-Atlantic orders impacts that of global international society. ${ }^{2}$

\section{Russia between east and west}

After Vladimir Putin became president in 2000 , one of his initial tasks was to establish longterm relationships with each player in Eurasia, with the aim of addressing regional dynamics, competing with other regional actors, and advancing Moscow's short-term situational objectives. However, Russian strategists ultimately concluded that the age of alliances was over and thus Moscow's ability to interact diplomatically and economically with different countries, including its new (sometimes strategic) partners, would assist Russia in sustaining its regional influence. At the same time, Russia's post-Cold War experience and its deep-rooted ire with the West led to its increasingly assertive behaviour in certain spheres, the so-called aggressive defensiveness in its foreign policy, and to growing ties between Moscow and Beijing. According to Moscow, Russian interests were not accounted for in deliberations with the West, as in the early 2000s, nor when the president was the more liberal-leaning Dmitry Medvedev, who supported sanctions against Iran and endorsed a no-fly zone over Libya. After 2012, the so-called Putin Doctrine in foreign policy was moulded and Aleksander Nevsky's famous dictum, "We must strengthen the defence in the West, and look for friends in the East" became increasingly relevant.

Moreover, following Putin's return as president in 2012, Moscow articulated in greater depth its "pivot to the East" policy. It had initially been developed in the mid-2000s as a belated policy response to the East's spectacular rise, although Russia's desires to diversify its diplomatic partnerships date back to the 1990s. Recent tensions between Russia and the West over crises in Ukraine and the Middle East have encouraged Moscow's pivot to become more pronounced, intensifying Sino-Russian cooperation on an unprecedented level. Moscow and Beijing have now signed many energy accords worth hundreds of billions in USD, although the significance of these deals is contested (Bolt \& Cross, 2018). At a meeting in Moscow on 8 May 2015, Putin and Xi agreed to integrate their two aforementioned projects: the Silk Road Economic Belt (SREB) - now known as the Belt and Road Initiative (BRI) - and the Eurasian Economic Union (EEU).

Russia's declared intention to pursue international integration according to a "Greater Eurasia" paradigm places it in an intermediate position between the two aforementioned orders for an extended amount of time, still discursively and normatively dependent on the West (Morozov, 2015, pp. 103-134) but increasingly integrated with the East. It will take years before the full impact and shape of the EEU and BRI become clear, meaning that Moscow and Beijing's respective, long-term international postures and capabilities will remain difficult to ascertain for the time being, as each party's relationship with Western states will depend in part on the "success" or "failure" of these integration projects. Furthermore, this interim period will also feature a preoccupation of major global 
actors with their own domestic issues: China's need to shift away from an export-based economy toward one more rooted in domestic consumption, the European Union's plans to pursue eurozone reform and address the migrant crisis in institutional form, and the United States' newfound pursuit of protectionism against the background of an increasingly partisan and dysfunctional political system. In short, the result of Russia's declared "pivot to the East" could take years to manifest itself fully. It could be that Moscow is pursuing Eurasian integration merely as a means of strengthening its hand in its relationship with Europe, with Russia's ultimate desire remaining European integration albeit on terms more equal than a Brussels-centric order. Alternatively, historians may look back on the Ukraine crisis as the moment when Russia definitively broke from Europe and the West.

Russia's very crafting of a "Greater Eurasia" vision following its failure to persuade Ukraine to join the EEU represents an admission of weakness, as the plan relies upon Chinese participation rather than being centred on a self-sufficient post-Soviet space (Lukin, 2018). And as time goes by, the balance of power in Central Asia is likely to favour China, for reasons ranging from Russia's relative economic decline to China's increasing consumption of natural resources from and its growing activism in the region (A. Gabuev, personal interview by author. Moscow, November 30, 2017). That said, there are several mitigating factors that work against Moscow becoming Beijing's junior partner in global affairs, such as Russia continuing to enjoy an overwhelming preeminence over China when it comes to nuclear weapons. Moreover, although many possible futures exist, a likely outcome of China's political rise and increasing self-sufficiency is a worsening of relations not only with countries in East, Southeast and South Asia, but also with the United States itself (White, 2013). In such a scenario, China will need to maintain good relations with Russia to avoid encirclement (D. Suslov, personal interview by author. Moscow, September 11, 2017). Additionally, becoming China's junior partner is a question of degree. For example, it is difficult to imagine the process going so far as to result in a situation where Russia, which thinks of itself as a great power in its own right, would regularly set aside its UN Security Council veto for China's benefit (A. Gabuev, personal interview by author. Moscow, November 30, 2017).

To be sure, Russia is open to Chinese leadership on certain political matters in Eurasia, such as the North Korean issue (A. Kortunov, personal interview by author. Moscow, September 25, 2017). Moreover, while it does attempt to deepen ties with the likes of Tokyo and ASEAN, Moscow has not mobilized overwhelmingly to hedge against China's growing influence in East Asia, thus representing a "gradual accommodation to China's pre-eminence" (Kaczmarski, 2015, p. 167). China's predominance could appear less threatening or overwhelming if Beijing is bound into some sort of Eurasian multilateral mechanism, with the recent expansion of the Shanghai Cooperation Organization (SCO) to include India and Pakistan coming to mind, thus acting as a break on unbalanced bilateral relationships in Eurasia that feature a powerful China and a less powerful counterpart (Trenin, 2017). Finally, it could be that Russia is less interested in its specific relative power vis-àvis China than it is in being recognized as a great power with legitimate interests and a sphere of influence. This suggests that irritants in Sino-Russian relations could be dealt with in a cooperative rather than an adversarial fashion. All of this implies that the complex and multifaceted relationship between Moscow and Beijing is of a different 
nature to the former's efforts to balance against the West (Korolev, 2016), which seemingly denies the legitimacy of Russia's interests and influence in Eastern Europe.

Moreover, Moscow has had more time to adjust to Beijing's gradual rise than it had to adapt to the Western pre-eminence that immediately emerged upon the Soviet Union's collapse. It may be convinced at this point that China "has limited aims and is a riskaverse world power" due to the "self-restraint that it has exercised toward Russia at the bilateral, regional and global levels (Kaczmarski, 2015, pp. 169-170). Indeed, when it comes to Russia and China's shared neighbourhood in Central Asia, Beijing "makes no overt effort to question Russia's role in the region, avoiding the zero-sum dynamics that have led to numerous conflicts between Russia and the West and could otherwise cause tension in the region" (Stronski \& Ng, 2018). In other words, unlike in the Euro-Atlantic order and despite China's meteoric economic rise, the Sino-Eurasian order has not featured a rapid rightward swing of the pendulum on normative issues at Russia's expense. To use English School vernacular, Russia's relationship with China has been marked by relative pendular stability, including the construction of multilateral, inclusive security mechanisms such as the SCO.

Of course, none of the above guarantees that Russia's relations with China - particularly in Central Asia - will not grow more complicated over time. These relations, however, are clearly multifaceted, which speaks against the application of structural theories such as neorealism to explain the forces that drive the Sino-Russian relationship. As noted, we conceptualize Russia's post-Cold War relationship with the international societies to which it belongs as being dependent upon two vectors: the evolution of the Sino-Eurasian order and the evolution of the Euro-Atlantic order. An agreed-upon legitimacy was lacking in Moscow's post-Cold War relationship with the Euro-Altantic order (Sakwa, 2017, pp. 1168), as that order underwent an overly rapid rightward pendulum swing as Washington sought to consolidate a unipolar Atlanticist Europe that largely excluded Russia.

It is important that we clarify what is meant by "agreed-upon legitimacy" here: We refer not only to the content in question but to the perceptions and expectations surrounding it. Russia's overwhelming material and normative dependence on the West, as noted above, suggests that Moscow had more ambitious expectations for its post-Cold War relationship with the West than it did initially for its ties with China. Indeed, in the early 1990s, in line with Moscow's support for the Western security agenda in Serbia and Iraq and its desire to integrate into Western institutions (Tsygankov, 2013, p. 72), Russia went so far as to discuss the possibility of having some form of NATO, UN or OSCE involvement in stabilizing those areas of the former USSR where ethnic conflict had broken out. However, Moscow's expectations were met with disappointment. The initial trade-off expected by Gorbachev that was to bring Cold War-era hostilities to an end - freedom of choice for Warsaw Pact states in exchange for a promise of non-interference by the West in Russia's internal affairs - did not see Western states uphold their end of the bargain. Moreover, to many Russians the West appeared more interested in weakening Russia and causing the communist economic system to collapse than it was in helping it to establish a veritable rule-of-law system and social safety net (Tsygankov, 2013, p. 121).

To summarize, the amount of content Russia shared with the Euro-Atlantic order was thick - rooted in profound desires related to identity and regional architecture - but agreement on that content was thin. Russia wished to "return to Europe" after having been cut off by the Iron Curtain and expressed its will to join the West through the creation of a new 
"Greater Europe", but ultimately was unable to find a partner that could fully accommodate its desires (Sakwa, 2017, p. 18). By contrast, although Moscow and Beijing do not have identical national interests, Russia's relationship with and expectations from the Sino-Eurasian order were thin, but there has thus far proven to be a sufficient amount of agreement concerning the relevant content, including (at least nominal) respect for Russia's supposedly legitimate great-power aspirations and sphere of influence. Whether this will remain the case as Russia's decline progresses and China's rise continues remains an open question, but already we can draw one conclusion: Normatively thin orders are not necessarily unstable, so long as they are properly managed. In the case of Russia's relationship with the Euro-Atlantic order, however, diverging expectations and norms combined with an overly hasty rightward pendulum shift to produce an even greater (and unstable) normative divide between Russia and the West.

This model allows for the fact that Russia-China relations are now mature enough not to be entirely dependent upon the West, while at the same time noting that Moscow's supposed wariness of Beijing can be mitigated if the latter adopts a restrained approach toward the former. It also allows us to conclude that Russia, most of whose population is in Europe, will remain open to resuming a Western-oriented predisposition in the future if it perceives the threat level emanating from the West as low.

\section{Russia's influence in Eurasia}

The dissolution of the Soviet Union in 1991 raised the dilemma for policymakers in Moscow of how to give proper form and meaning to its new relationship with the heartlands of the former tsarist and Soviet empires. Many of the territories that had been an integral part of Russia in its different guises had practically overnight become independent countries. The way that ties with the former empire were to be given shape was intricately connected to Russia's international orientation and self-conception. The main goal of the new Russian elite was to transform the country into a free-market democracy, and it was only by developing partnerships with more economically and politically "advanced" Western states such as the US, Germany and France that Russia could succeed in this transition. This would take priority over Moscow's relationships with the ex-Soviet republics, a strategy reinforced by the argument that Russia's imperial burden was holding back its development. In the event, this period of almost unconditional pro-Westernism proved short-lived, initially owing to a period of sustained economic turbulence and disorder plaguing the former Soviet republics on Russia's periphery (Kuchins \& Zevelev, 2012, pp. 199200). This paved the way for renewed attention toward the post-Soviet space, especially under the leadership of Foreign Minister and later Prime Minister Yevgeny Primakov, who championed the concept of a multipolar world with Russia constituting one of its poles.

The rise of Vladimir Putin to power in 1999 did not solve Moscow's conundrum concerning the nature of its relationship with the West, despite his designation of relations with Europe and the US as a priority at the start of his first term. The failure to grasp this opportunity and establish a genuine and productive partnership can arguably be blamed on the short-sightedness of Western chancelleries. A host of actions by the US, including its 2002 withdrawal from the ABM Treaty, its invasion of Iraq in 2003, and its alleged support for so-called "colour revolutions" across the post-Soviet space left 
Russian leaders disappointed and deeply cynical vis-à-vis the West. The result has been a more assertive course set by Moscow, buoyed by high oil prices, and the renewed importance of the post-Soviet region for Russian policymakers. This was given institutional shape through the project of Eurasian integration, embodied in the Eurasian Economic Community and later Union (EEU). Moscow's official line is that the EEU would function as a stepping stone for an "integration of integrations", making possible the "Greater Europe" that Gorbachev had striven for. A more cynical view is that the EEU was simply designed to provide an instrument through which Moscow could carve out a sphere of influence for itself in its "near abroad". Indeed, Moscow's newfound assertiveness has been accompanied by a not always benign reassertion of what Dmitry Medvedev called Russia's "sphere of privileged interests" (Kremlin, 2008), evidenced by heavy-handed tactics such as trade wars and embargoes as well as, in Georgia's case, outright military conflict.

Following the continued rise in Russia-West tensions in 2011-12 over Libya and protests in Moscow, the eruption of the Ukraine crisis in 2014 marked a definitive end to Russia's persistent dilemma of crafting a coherent foreign policy toward the West. As Trenin asserts, it "served as the coup de grâce for the two concepts that had guided Russian foreign policy since the break-up of the Soviet Union: integration into the wider West and reintegration of the former republics with Russia" (Trenin, 2017). As is well known, the revolution in Kyiv that would eventually lead to the toppling of President Viktor Yanukovych in February 2014 was prompted by his last-minute rejection of Ukraine's proposed Association Agreement with the EU, which was done at Moscow's behest. From the Kremlin's perspective, the expansion of EU influence and the admission of new NATO members had often gone hand in hand throughout the 1990s and 2000s (Mearsheimer, 2014). Now it was time for Moscow to push back.

At the same time, the annexation of Crimea and the ensuing proxy war in eastern Ukraine made hitherto loyal Russian allies such as Belarus and Kazakhstan more apprehensive, in addition to completely estranging the new rulers in Kyiv. Accordingly, the goal of "small" Eurasian integration - that is, solely amongst Soviet successor states - took a fatal hit as Ukraine would not sign up to the EEU, while other member states sought to curb the supranational tendencies of the project and its overall competences for fear of surrendering their sovereignty to Moscow. As the first deputy prime minister of Kazakhstan said upon signing the treaty in May 2014, "We are not creating a political organization; we are forming a purely economic union (...) we don't meddle in what Russia does domestically, and they cannot tell us what foreign policy to pursue" (cited in MacFarquhar, 2014). Ironically, the supranational features of the EEU were precisely meant to keep Russian power in check by an extensive rules-based set of mechanisms, thereby acting as a reassurance for the union's smaller members (Dragneva \& Wolczuk, 2017). This conundrum, born out of apprehension over Russian domination, is perhaps the most important challenge to the overall viability of the project.

With the viability of the EEU in question and the prospects for a "Greater Europe" let alone a "Greater West" - in tatters, Russian leaders turned to the idea of a Greater Eurasian Partnership, spanning not just the post-Soviet region but also Turkey, Iran, South Asia and East Asia. The new approach is not so much a "pivot to the East", as both Kremlin pundits and Western commentators have argued (Karaganov, 2016; Lo \& Hill, 2013), but can rather be interpreted as a new construct in which Russia situates itself at the core 
of an entity encompassing the entire Eurasian supercontinent. Sakwa calls this "bicontinentalism", a geopolitical approach in which Moscow enjoys an advantage from its geographic location by playing off "Western' against 'Eastern' orientations" (2015b, pp. 6569). Thus, bicontinentalism in Sakwa's vocabulary is not only a geographical term but also a foreign policy strategy that grants Moscow freedom of manoeuvre. In this context, the EEU remains a site of priority, notably in view of linking up with China's BRI (Luzyanin, 2018). However, the new Eurasian vision is also underpinned by the SCO, which since 2017 counts India and Pakistan as its members, thereby spanning most corners of the Eurasian landmass.

Although Russia intended to re-emerge as a significant political and economic player in Eurasia, its influence has in fact declined since 1991. A factor that confirms a major contradiction in the study of Russian foreign policy since 2001 is that while Moscow executes a very astute foreign policy with its limited resources and capabilities, playing an important role in various global and regional conflicts, its influence and presence in the regions traditionally viewed as Russia's "privileged sphere of interests" continues to decline. As noted in the previous section, Moscow now shares Central Asia with Beijing. But beyond this, the influence of mere regional powers such as Iran in many ways exceeds that of Russia in places where Moscow once reigned supreme, such as Afghanistan, Iraq and to a certain extent even Syria. Russia is incapable of seizing the leading reins in many key regions in the Eurasian core.

\section{Forms of international legitimating principles and rising normative agreement between Moscow and Beijing}

It is important to note that when Putin first assumed the Russian presidency, his main priorities with regards to relations with China were to continue and enhance normalization, rather than establish or strengthen any strategic alliance. Unlike Primakov, Putin seemed uninterested in creating a strategic "axis" between Russia and China to balance against the US and the rest of the West (Tsygankov, 2009, p. 10). In the wake of the terrorist attacks of 11 September 2001, the idea of multipolarity was abandoned, instead focusing on "pragmatism and self-concentration" in the international arena (Tsygankov, 2010, p. 134). Putin's initial National Security Concept placed emphasis on issues such as terrorism, separatism, corruption and organized crime instead of multipolarity. To the astonishment of China's political elite, Putin gave preference to partnership with the West over the East. As Shevtsova and Shakleina report, when he came to power, Putin was open to the influence of and even sought contacts with Western states (Shevtsova, 2010, pp. 47-52), trying once again to "reach out to the West" (Shakleina, 2012, p. 164). Just as Boris Yeltsin and his foreign minister Andrei Kozyrev had done nearly a decade earlier, Putin hoped for a full partnership with the Western world which would secure Russia's modernization and integration into the Western economic institutions (Shevtsova, 2010, pp. 47-52).

However, by the mid-2000s, Putin's Russia became disillusioned with the West and Statists and Sinophiles in the government began to advocate for an alliance with China, proposing to use the SCO as "a geopolitical counterweight to NATO" (Trenin, 2012, p. 4). It is in this context that the improving post-Cold War relationship between Moscow and Beijing should be understood: resting on a set of normative issues, including opposition to Western - and particularly American - hegemony in international arena and the protection 
of non-Western states' sovereignty including "the independence of national interests and the diversity of political systems" (Kim \& Indeo, 2013, p. 276). Both countries are also sceptical about the views held by democratic universalists and uphold traditional interpretations of national sovereignty and non-interference in other countries internal affairs. Officials in both Moscow and Beijing were very critical of George W. Bush's interventionist "Freedom Agenda", aggressively promoted in 2000s by his administration worldwide. The two countries' officials have on many occasions stated that Bush's "War on Terror" has failed, while the invasion of Iraq has actually increased the worldwide threat of terrorism. Furthermore, the Russian and Chinese leaderships believe that American policies produced "colour revolutions" in countries such as Georgia, Kyrgyzstan and twice in Ukraine (Weitz, 2008, p. 37). Russia and China have come to doubt the genuine neutrality of many international bodies, which they consider as "United States-centred" (Rozman, 2014 , p. 245). The political establishments of both countries are extremely critical of the West's use of NGOs to interfere in sovereign countries' internal affairs.

The two countries' political elites are sceptical of the possibility of transforming authoritarian states into functioning democracies and fail to understand how overthrowing a dictator necessarily leads to the emergence of democracy, as had seemingly been promoted by many Western democratic determinists and neoconservatives in the 1990s and 2000s. The Western intervention in Libya, according to Sakwa, was one of the main reasons attributed to Putin's return to the presidency in 2012, as it confirmed Russia's suspicions regarding Western intentions in the Middle East (Sakwa, 2015a, p. 572). On 17 March 2011, following a UN Security council vote, NATO established a no-fly zone over Libya. Russia's political establishment believes that Western states once again tricked Russia by calling for Medvedev to abstain from voting on the famous UN Security Council Resolution 1973. The resolution authorized a no-fly zone over Libya which later developed into a full-scale bombing campaign targeting the country's infrastructure and enabling the overthrow of Libyan leader Muammar Gaddafi (Kremlin, 2011). Hillary Clinton's psycho-ecstatic laugh when watching Gaddafi being tortured and killed, exclaiming, "We came, we saw, he died," caused a huge debate in Russian society, with commentators accusing Medvedev of betraying Libya and its people (Odnako, 2013; RT, 2016).

Following these events, Russia's "turn to the East" policy, originally announced in 2010, became "more pronounced" and transformed the Sino-Russian relationship into a "closer partnership that included cooperation on energy trade, infrastructure development, and defence" (Trenin, 2015). Both Russia and China had been critical of the American response to the onset of the so-called Arab Spring. But Washington's behaviour during the Ukraine crisis, where the perception was that US officials participated in a coup d'état against an extremely corrupt but democratically elected president, was the last straw, pushing Moscow and Beijing even further toward consolidating their "strategic partnership". This perception may have been rooted in paranoia, the result of Russia failing to devise a strategy for dealing with its former imperial possessions - and Ukraine in particular - that is workable in the post-Soviet context (Trenin, 2018a). But as mentioned above, perceptions and expectations are crucial. Moscow's belief in its right to a sphere of influence and its wariness of NATO's eastward encroachment have been guiding principles of Russian foreign policy for much - if not all - of the post-Cold War period. Its expectation that the West would be understanding of its needs and desires, precisely when its normative dependence on the West was at its apex following its "return to Europe" at the end of the 
Cold War, ultimately produced a volatile relationship when it appeared as if those needs and desires were being disregarded. A perceived attempt to strengthen Atlanticist hegemony in the European neighbourhood - a rightward swing of the pendulum - encouraged Russia to push back and send the pendulum leftward. Not all, however, is rosy in Russia's relationship with China, as the next section will show.

\section{Sino-Russia relations in an evolving Eurasia}

Several key concerns have been invoked in Russia's China discourse since 1991. They include: (1) Russia becoming China's raw material appendage; (2) the disappearance of Central Asia from Russia's sphere of privileged interests; (3) transformation into China's "junior partner"; and (4) the perceived Chinese takeover of the Russian Far East due to the influx of Chinese workers and China's increased presence there. Interestingly, the "China threat" was present in Russia's public and official discourse until 2012, when, in conjunction with Moscow's emphasis on its "pivot to the East", official Russian discourse began to treat the idea of a "China threat" as taboo (Kuhrt, 2016).

The evident disparity in power certainly increases the risk of Russia becoming a "junior partner in a Beijing-led coalition" (Tsygankov, 2009, p. 17). Globally, the Chinese defence budget is second only to the US, with Beijing planning to acquire three aircraft carries, for instance, while Russia is ranked fifth with only one such operational carrier. In the 1980s, the GDP of the Russian Soviet Federative Socialist Republic (the Russian titular republic within the USSR) was 60 per cent larger than that of China, whereas by 2010 postSoviet Russia's economy was four times smaller than China's (Trenin, 2012, p. 8). While Beijing plays a very important role in Moscow's international trading partnerships, China's most important trading partner is the US, with Russia occupying a marginal place (Spanger, 2016). The trade structure is a clear indication that Russia's concerns about morphing into China's raw material appendage are not entirely groundless. In 1999, for instance, Russia's Chinese imports were diverse, consisting of processed and unprocessed goods such as metals, plastic, textiles, footwear and machinery. By 2015 more than half of Chinese exports to Russia were hi-tech and machinery. In 1990, only six percent of Russia's exports were hydrocarbons and raw materials, while 39 per cent were machinery. By contrast, by 2013 a staggering 74 per cent of Russia's exports were hydrocarbons and raw materials (e.g. gas, oil and timber), with only 4 per cent being machinery and processed goods (Spanger, 2016). In short, Russia appears to be turning into "an oil well", where China simply takes its raw oil and gas.

In this context, Russia's political elite has indeed grasped that China's colossal Belt and Road project is not only about building roads from China to Europe, particularly as Beijing is anticipated to continue to rely on existing and more trustworthy and economically viable shipping methods. China's grand vision is rather about the emergence of a dynamic and promising economic space in which Beijing finds itself as the centre of prosperity and growth. Many critics maintain that China's main interest in Russia is due to its geographic location, in which Russia is considered as a source of raw materials, a card to be played against the West, and a road to transport Chinese goods to Europe. This notion of Russia acting as Beijing's catalyst to achieve its global ambitions is prevalent in popular Russian discourse. For example, the celebrated novelist Vladimir Sorokin has written dystopian novel in which Russia emerges as a road from Guangzhou to Paris. In the book, the 
road embodies the country's arteries and veins, bruised by crimes and horrors (Sorokin, 2006, p. 46). Meanwhile, Russian strategists and the Kremlin-loyal political elite prefer to pretend that China's Belt and Road addresses another integration project - in that it could be integrated with the EEU - rather than admit that it asserts Chinese hegemony in Eurasia and ultimately represents an attempt to construct a Sino-centric regional order. Sergei Karaganov (2016) suggests it was the Russian diplomat Igor Morgulov who proposed the idea of linking the EEU with the BRI. The initiative to coordinate the two appears to be a move by Moscow to mask yet another concession to China and appear as one of Eurasia's key players instead of China's junior partner, while strategists stall for time so as to examine ways to curb China's seemingly unstoppable rise in Eurasia.

Russia has thus far managed to establish a tacit if somewhat facile agreement with China in which Beijing recognizes Russia's regional interests - or at least pretends to do so. Indeed, Moscow's political technologists have been successful in shaping a narrative where Russia and China are strategic partners, with both being major and equal players in Eurasia, proposing to link their respective integration projects and calling it a form of sopriazhenie. ${ }^{3}$ China has reciprocated, is playing along with Russian pretences, and is likely to continue to do so as long as this suits its interests. To the Russian public, Moscow consequently appears as a key player in Eurasia, one equal to Beijing instead of in the role of "junior partner". In the meantime, Russia has managed to gain the time the Kremlin desperately needs to find ways to address China's rise in Eurasia and explore the means necessary to adjust itself to the new realities of twenty-first century Eurasia.

\section{Russia's future foreign policy vectors}

The rupture in Russia-West relations brought on by the Ukraine crisis is a fundamental and systemic one, rooted in opposing conceptions of order for both Europe and the world. The crisis also revealed the fact that both Russia and the West have pursued contradictory foreign policy aims over the past quarter-century. Russia cannot pursue good relations with the West while at the same time trying to dominate its backyard, as the latter violates the principle of the "right to choose" one's foreign policy orientation that Western states believe applies to all European countries, as per the Paris Charter (Paikin, Merlen, \& Ivanchenko, 2018). Washington and Brussels, for their part, made the mistake of undertaking the expansion of NATO while simultaneously telling the Kremlin that this process was not directed in any way against Russia. This, too, was contradictory, as pledges to protect formerly communist countries were obviously viewed in Central and Eastern European capitals as insurance against a potentially revanchist Russia. Sakwa terms this rivalry between Russia and the West a fundamental conflict between "norms and spatiality" (Sakwa, 2016, pp. 87-88). As such, it is difficult to imagine normal diplomatic attempts to diffuse tensions as being sufficient to repair the chasm that has now opened along Europe's peninsular perimeter stretching from St. Petersburg to Rostov-on-Don, as the problem is structural in nature.

Seen against this background, it is no surprise that every American presidential administration in the post-Cold War period has begun with attempts to reset its relationship with Russia, only to see these efforts frustrated by what appear to be fundamentally incompatible worldviews (Stent, 2014). The situation has only been worsened by the sense of 
betrayal in Moscow, the product of the sheer speed and scope of the pendulum's rightward swing in Europe after the fall of the Iron Curtain at a moment when Russia's normative dependence on the West was increasing, following the collapse of the Iron Curtain and Russia's attempt to "return to Europe". Further evidence of the structural nature of the dilemma has been provided by Timofeev (2018), who claims that the negotiated stability on the European continent, embodied in the Helsinki order, had collapsed along with the Soviet Union: A balance of power was replaced with an imbalance of power, and strong states were replaced with quasi-failed ones in the post-Soviet space and no longer fully sovereign ones in the EU after Maastricht. It is impossible to envisage the creation of a stable security order in Europe so long as the continent's militarily most powerful country - Russia - remains excluded from its most important institutions.

One or both sides of the Russia-West divide will need to revise their ordering principles and norms for the impasse to be broken, and even this is no guarantee of success. The chances of this happening are not high, at least over the medium term. The EU remains itself seemingly trapped in a liminal condition between supranationalism and sovereignty for its member states, and this is likely to remain the case as long as populists remain strong political forces on the continent. In this context, the sanctions that Brussels has imposed on Russia represent one of the few signs of continental unity and will thus prove difficult to lift (Kortunov, 2018). The EU remains a rules-based order, and as it believes that Moscow is responsible for breaking the rules by undermining Ukraine's sovereignty, it is unlikely to change course. Russia, for its part, is still emerging from its extremely tumultuous and disorienting twentieth century, clinging to the principles and norms it knows best, perhaps even as a form of ontological security and national unity. Barring a significant overture from the West, it is difficult to imagine Moscow's disposition changing, as Russia appears to have weathered the worst of the economic sanctions and thus has little incentive to compromise on what it considers to be a core national security interest. On top of this, many among Russia's political elite believe it is impossible to make a deal with the US or EU after leading Western states reneged on their pledge to allow Yanukovych to remain in power in Ukraine so long as early elections were held.

Over the longer term, it is possible that the EU will develop into more of a coalition of the willing, with sets of member states pursuing different tracks of integration. The EEU, for its part, is also a coalition of the willing of sorts, with only a select few states in the postSoviet space participating. This could be the basis for the eventual development of a more flexible European order. Indeed, as mentioned above, Moscow has been at pains to stress that the "Greater Eurasian" order remains open to EU participation, although this could be the result of one or several different factors, ranging from Russia's continued normative dependence on Europe, to the requirements for its economic modernization, to the strategic realities related to its proximity to the European peninsula, to its desire not to be entirely dependent upon China.

As it is difficult to see any substantial change in US-Russia and EU-Russia relations over the medium term due to structural reasons, Moscow will remain dependent on Beijing for the time being. Yet the Russia-China relationship rests on mixed foundations. On the one hand, their rapprochement is the result of genuine normative convergence, partially in response to Western actions. This suggests that their relationship is more substantive than a mere "axis of convenience", as previously suggested by Lo (2008). This situation is likely to endure so long as both countries continue to view the United States and the 
broader West as a greater security threat than each other. Indeed, it is remarkable that the Sino-Russian partnership has survived a power transition between the two countries despite deep mutual historical suspicion (Deng, 2008, p. 153).

That said, Russia's apprehension at becoming China's junior partner is real, and it fears being reduced to a second-tier power in its own backyard (if it hasn't already become one). Beijing has thus far been careful to limit its aims in regions such as Central Asia, restricting them mostly to the economic sphere and keeping those in the security sphere tightly focused on issues specific to Chinese security such as cross-border counterterrorism and fighting the drug trade (Stronski \& Ng, 2018). The approach taken by the different major powers in their respective shared neighbourhoods with Russia is telling. Unlike Washington and Brussels, who argue that Ukraine's foreign policy orientation is none of Russia's business, Beijing has not challenged the legitimacy of Russia's presence in Central Asia. The more China is able to prove its bona fides as a responsible, conservative and measured rising power, and the more it builds confidence with Moscow by keeping the Sino-Eurasian order focused on a clear (but not inflexible) set of agreed-upon principles, the more likely we are to witness the long-term stabilization of the Sino-Russian relationship. This set of agreed-upon principles could be further buttressed depending on the evolutionary course that Russia takes over the coming decades: If it can transform itself from a fallen and subaltern power focused primarily on preserving its European sphere of influence into an independent and dynamic entity firmly and confidently situated at the northern end of Eurasia (Trenin, 2018a), the prospects for a more fullyfledged shared worldview between Russia and China will increase.

\section{Conclusion}

Despite their increasing breadth and maturity over the course of the post-Cold War period, it still appears as if Sino-Russian normative relations today remain largely dependent on a negative rather than a positive agenda, rooted in opposition to American hegemony rather than substantive content. Even fledgling attempts to order Eurasia, such as the SCO, still reference anti-hegemonial principles. For now, Russia feels as though it has earned China's respect as an equal partner, something it has failed to achieve in its relationship with the West. Whether Moscow truly trusts Beijing, however, remains an open question. Future research could focus on comparing the cultural, economic and political norms held respectively by Russia and China, and whether there is sufficient overlap to suggest that a thicker international society could emerge featuring these two Eurasian giants - one rooted in shared values in a fashion similar to the transatlantic community, in contrast with the somewhat regulatory and technical relationship that characterizes their pledge to coordinate the EEU with the BRI.

Over the medium term, while the Sino-Russian alignment may have stabilized the international system from a neorealist perspective, there now exist several flashpoints where the Russian and Western spheres of influence meet: in the Baltics, Ukraine, the Middle East and Northeast Asia. Russia's current liminal position - situated ontologically and politically in both the West and the East but securely in neither of the two - remains a source of international instability, or at the very least uncertainty. Over the long term, though, it would represent remarkable historical symmetry if Russia's relationship with China surpasses the importance of its relationship with Europe and the broader West. After five 
centuries of the dominance of naval power and exploration, with Russia focused on both fending off and emulating European states, the Eurasian Heartland may now be taking centre-stage in international politics, with Russia's primary focus shifted eastward for the first time since the years that followed the dissolution of the Mongol yoke. In the meantime, Moscow and Western capitals would do well to show restraint, to ensure that the tensions caused by the rapid post-Cold War swing of the pendulum in the Euro-Atlantic theatre are brought under at least a modicum of control and that normative and regulatory competition between them does not dramatically escalate. We are already beginning to see a degree of this from Brussels, which has recently agreed to a more limited form of cooperation with Yerevan than the more far-reaching Association Agreement it had previously negotiated with Kyiv (Devyatkov, 2018).

Finally, while Reus-Smit and Dunne's recent edited volume on the "globalization of international society" (i.e. that it emerged historically from several intermingling sources across the globe) has provided an important contribution to the English School canon, the case of modern Russia - colonizing itself on behalf of Europe, as Morozov puts it lends at least a degree of credence to Bull and Watson's famous "expansion of international society" narrative (i.e. that it originated in Europe and then spread to encompass the entire globe) (Bull \& Watson, 1985). An exploration of the Globalization and Expansion accounts designed specifically to determine the degree of theoretical and historical overlap between them, with the aim of reaching tentative conclusions for great-power behaviour in the twenty-first century and the future of international order, appears to be a promising avenue for practically inclined scholars with an interest in English School concepts.

\section{Notes}

1. Several scholars have covered this topic. For example, Roy Allison (2013) shows how the U.S. invasion of Iraq and Western recognition of Kosovo influenced Russian foreign policy doctrines, while Richard Sakwa (2017) analyses how Western attempts to consolidate a unipolar order after the USSR's collapse produced international disorder due to Moscow's rejection of the notion that Western leadership is synonymous with order itself.

2. It is worth emphasizing that this article's model of multiple societies to which Russia simultaneously belongs does not challenge the notion that there also exists a single, overarching, global international society.

3. From the verb sopryach'/sopriagat', meaning to mate, combine, associate.

\section{ORCID}

Camille-Renaud Merlen (1) http://orcid.org/0000-0003-3398-1100

\section{References}

Allison, R. (2013). Russia, the west, and military intervention. Oxford: Oxford University Press.

Bolt, P., \& Cross, C. (2018). China, Russia and twenty-first century geopolitics. Oxford: Oxford University Press.

Bull, H., \& Watson, A. (Eds.). (1985). The expansion of international society. Oxford: Oxford University Press.

Buzan, B. (2014). An introduction to the English school of international relations. Cambridge: Polity. 
Cox, M. (2013). Power and the liberal order. In R. Friedman, K. Oskanian, \& R. Pacheco Pardo (Eds.), After liberalism? The future of liberalism in international relations (pp. 103-116). Basingstoke: Palgrave Macmillan.

Deng, Y. (2008). Beyond alliance? China's strategic partnerships with Russia and India. In Q. Zhao, \& G. Liu (Eds.), Managing the China challenge: Global perspectives (pp. 151-176). Abingdon: Routledge.

Devyatkov, A. (2018). An EU-Russia modus vivendi in the east? Carnegie Moscow Center, 17 January 2018. Retrieved from https://carnegie.ru/commentary/75283

Dragneva, R., \& Wolczuk, K. (2017). The Eurasian economic union: Deals, rules, and the exercise of power. Chatham House Research Paper.

Dunne, T., \& Reus-Smit, C. (2017). The globalization of international society. Oxford: Oxford University Press.

Flockhart, T. (2016). The coming multi-order world. Contemporary Security Policy, 37(1), 3-30.

Kaczmarski, M. (2015). Russia-China relations in the post-crisis international order. Abingdon: Routledge.

Karaganov, S. (2016). From east to west, or greater Eurasia. Russia in Global Affairs, 25 October 2016. Retrieved from http://eng.globalaffairs.ru/pubcol/From-East-to-West-or-Greater-Eurasia-18440

Kim, Y., \& Indeo, F. (2013). The new great game in Central Asia post 2014: The US 'new silk road' atrategy and sino-Russian rivalry. Communist and Post-Communist Studies, 46(2), 275-286.

Korolev, A. (2016). Systemic balancing and regional hedging: China-Russia relations. The Chinese Journal of International Politics, 9(4), 375-397.

Kortunov, A. (2018). Europe and Russia: Four Scenarios for the New Cycle. Russian International Affairs Council, 25 April 2018. Retrieved from http://russiancouncil.ru/en/analytics-and-comments/ analytics/europe-and-russia-four-scenarios-for-the-new-cycle/

Kotkin, S. (2016). Russia's perpetual geopolitics. Foreign Affairs, 95(2), 2-9.

Kremlin. (2008). Interview given by Dmitry Medvedev to Television Channels Channel One, Rossia, NTV. Kremlin.ru, 31 August 2008. Retrieved from http://en.kremlin.ru/events/president/ transcripts/48301

Kremlin. (2011). Zaiavlenie Prezidenta Rossii v sviazi situatsiei v Livii. Kremlin.ru, 21 March 2011. Retrieved from http://kremlin.ru/events/president/news/10701

Kuchins, A., \& Zevelev, I. (2012). Russia's contested national identity and foreign policy. In H. Nau, \& D. Ollapally (Eds.), Worldviews of aspiring powers: Domestic foreign policy debates in China, India, Iran, Japan and Russia (pp. 181-209). Oxford: Oxford University Press.

Kuhrt, N. (2016). Russian and China: Competing or complementary priorities. China Policy Institute, 14 April 2016. Retrieved from https://cpianalysis.org/2016/04/14/russia-and-china-competing-orcomplementary-priorities/

Lo, B. (2008). Axis of convenience: Moscow, Beijing, and the new geopolitics. Baltimore, MD: Brookings Institution Press.

Lo, B., \& Hill, F. (2013). Putin's pivot: Why Russia is looking east. Brookings, 31 July 2013. Retrieved from https://www.brookings.edu/opinions/putins-pivot-why-russia-is-looking-east/

Lukin, A. (2018). Putin's Silk Road Gamble. Washington Post, 8 February 2018.

Luzyanin, S. (2018). Greater Eurasia: The common challenges for China and Russia. Valdai Club, 16 April 2018. Retrieved from http://valdaiclub.com/a/highlights/greater-eurasia-the-commonchallenges/

MacFarquhar, N. (2014). Russia and 2 neighbors form economic union that has a Ukraine-size hole. The New York Times, 29 May 2014.

Mearsheimer, J. (2014). Why the Ukraine crisis is the west's fault: The liberal delusions that provoked Putin. Foreign Affairs, 93(5), 1-12.

Morozov, V. (2015). Russia's postcolonial identity: A subaltern empire in a Eurocentric world. Basingstoke: Palgrave Macmillan.

Neumann, I. (1995). Russia and the idea of Europe: A study in identity and international relations. Abingdon: Routledge.

Odnako. (2013). Pochemu sdali Liviiu. Posleslovie. Odnako, 23 January 2013. Retrieved from http:// www.odnako.org/blogs/pochemu-sdali-liviyu-posleslovie/comments/page-5/\#875410 
Paikin, Z., Merlen, C., \& Ivanchenko, V. (2018). Four years since maidan: Why Russia-west reconciliation will remain crucial during Putin's fourth term. Russia in Global Affairs, 16 March 2018. Retrieved from http://eng.globalaffairs.ru/book/Four-Years-Since-Maidan-Why-Russia-West-ReconciliationWill-Remain-Crucial-During-Putins-Fourth-Term

Rozman, G. (2014). The sino-Russian challenge to the world order. Stanford: Stanford University Press. RT. (2016). 'We came, we saw, he died': How Gaddafi was Hunted and Brutally Killed (TIMELINE). RT, 20 October 2016. Retrieved from https://www.rt.com/news/363454-timeline-gaddafi-deathanniversary/

Sakwa, R. (2015a). The death of Europe? Continental fates after Ukraine. International Affairs, 91(3), 553-579.

Sakwa, R. (2015b). Dualism at home and abroad: Russian foreign policy neo-revisionism and bicontinentalism. In D. Cadier, \& M. Light (Eds.), Russia's foreign policy: Ideas, domestic politics and external relations (pp. 65-79). London: Palgrave Macmillan.

Sakwa, R. (2016). External actors in EU-Russia relations: Between norms and space. In Avoiding a new 'cold war': The future of EU-Russia relations in the context of the Ukraine crisis (pp. 86-93). London: LSE Ideas.

Sakwa, R. (2017). Russia against the rest: The post-cold War crisis of world order. Cambridge: Cambridge University Press.

Sangar, K. (2017). Russia and China in the age of grand Eurasian projects: Prospects for integration between the silk road economic belt and the Eurasian economic union. Cambridge Journal of Eurasian Studies, 1, YDG5KF.

Shakleina, T. (2012). Rossiya i SShAv Mirovoy Politike. Moscow: Aspekt Press. 2012.

Shevtsova, L. (2010). Lonely power: Why Russia has failed to become the west and the west is weary of Russia. Washington, DC: Carnegie Endowment for International Peace.

Sorokin, V. (2006). Den' Oprichnika. Moscow: Zakharov.

Spanger, H. (2016). Russia's turn eastward, China's turn westward. Russia in Global Affairs, 17 June 2016. Retrieved from http://eng.globalaffairs.ru/number/Russias-Turn-Eastward-Chinas-TurnWestward-18251

Stent, A. (2014). The limits of partnership: U.S.-Russian relations in the twenty-first century. Princeton, NJ: Princeton University Press.

Stronski, P., \& Ng, N. (2018). Cooperation and competition: Russia and China in Central Asia, the Russian far east, and the arctic. Carnegie Endowment for International Peace, 28 February 2018. Retrieved from http://carnegieendowment.org/2018/02/28/cooperation-and-competition-russiaand-china-in-central-asia-russian-far-east-and-arctic-pub-75673

Timofeev, I. (2018). Unbalanced Europe and the new order in the OSCE space. Russian International Affairs Council, 3 May 2018. Retrieved from http://russiancouncil.ru/en/analytics-and-comments/ analytics/unbalanced-europe-and-the-new-order-in-the-osce-space/

Trenin, D. (2012). True partners? How Russia and China see each other. London: Centre for European Reforms.

Trenin, D. (2015). From greater Europe to greater Asia? The Sino-Russian entente. Carnegie Moscow Center, 9 April 2015. Retrieved from http://carnegie.ru/publications/?fa=59728\#

Trenin, D. (2017). Russia's evolving grand Eurasia strategy: Will it work? Carnegie Moscow Centre, 20 July 2017. Retrieved from http://carnegie.ru/2017/07/20/russia-s-evolving-grand-eurasia-strategywill-it-work-pub-71588

Trenin, D. (2018a). Russia and Ukraine: From brothers to neighbors. Carnegie Moscow Centre, 21 March 2018. Retrieved from https://carnegie.ru/commentary/75847

Trenin, D. (2018b). Russia as a disruptor of the post-cold war order: To what effect? In R. Passi, \& H. V. Pant (Eds.), Raisina files: Debating disruption in the world order (Vol. 3, pp. 18-23). New Delhi: Observer Research Foundation.

Tsygankov, A. (2009). What is China to us? Westernizers and Sinophiles in Russian Foreign Policy. Russie.Nei.Visions, 45.

Tsygankov, A. (2010). Russia's foreign policy: Change and continuity in national identity. Lanham, MD: Rowman \& Littlefield. 2010. 
Tsygankov, A. (2013). Russia's foreign policy: Change and continuity in national identity. Lanham, MD: Rowman and Littlefield.

Watson, A. (1992). The evolution of international society: A comparative historical analysis. Abingdon: Routledge.

Watson, A. (1997). The limits of independence: Relations between states in the modern world. Abingdon: Routledge.

Weitz, R. (2008). China-Russia security relations: Strategic parallelism without partnership or passion? U.S. Carlisle, PA: Army War College, Strategic Studies Institute.

White, H. (2013). The China choice: Why we should share power. Oxford: Oxford University Press.

Wight, M. (1977). Systems of states. Leicester: Leicester University Press. 